DOI 10.37882/2223-2982.2021.06.13

\title{
ИДЕИ НРАВСТВЕННОГО ВОСПИТАНИЯ К.Д. УШИНСКОГО И В.П. ВАХТЕРОВА В ПЕДАГОГИЧЕСКИХ ВЗГЛЯДАХ И ОПЫТЕ М.К. ТЕНИШЕВОЙ
}

\section{THE IDEAS OF MORAL EDUCATION OF K.D. USHINSKY AND V.P. VAKHTEROV IN THE PEDAGOGICAL VIEWS AND EXPERIENCE OF M.K. TENISHEVA}

\section{A. Zhbankov}

Summary: The article shows the connection of the ideas and pedagogical experience of the moral education of Princess M.K. Tenisheva, manifested in the agricultural school created by her, with the advanced ideas of the great teachers K.D. Ushinsky and V.P. Vakhterov in the late XIX - early XX centuries, as well as their significance in the development of the national theory of education.

Keywords: agricultural school, moral education, means of moral education, teacher's personality, persuasion, moral suggestion.
$\mathrm{B}$ конце XIX - начале XX веков известность в России имела сельскохозяйственная школа княгини М.К. Тенишевой. Замышляя создать в селе Талашкино Смоленского уезда «идейное имение», она создала в нем «идейную школу». «Идейную» - основанную на совокупности передовых педагогических идей того времени, относящихся к представлению княгиней об идеальной народной сельскохозяйственной школе «нового типа».

Анализ высказываний М.К. Тенишевой, описанных ею педагогических процессах и явлениях в созданной ею школе показал наличие в них заметных следов педагогических идей нравственного воспитания К.Д. Ушинского и его последователя В.П. Вахтерова, свидетельствующих о принятии их княгиней.

Единственным научным трудом, содержащим характеристику Талашкинской школы М.К. Тенишевой, является диссертация О.Э. Эрдман, защищенная в 1999 году. Автор диссертации излагает выявленное ею влияние идей «передовых деятелей того времени» с указанием направленности влияния каждого из них: И.А. Антонова, Е.Н. Андреева, К.Ю. Церкуля, Н.В. Касаткина, С.В. Владимирского, Д.К. Советкина, П.Ф. Лестгофта, И.А. Стебута [8, с. 24-26]. Однако в перечне идей названных выше персон направленность на нравственное воспитание в народных школах нами не обнаружена. Хотя в рассматриваемый период данная проблема обсуждалась в печати с выходом статей К.Д. Ушинского и В.П. Вахтерова.

\author{
Жбанков Алексей Алексеевич \\ Аспирант, Смоленский государственный университет \\ al_zh_xx@mail.ru
}

Аннотация: В статье показана связь идей и педагогического опыта нравственного воспитания княгини М.К. Тенишевой, проявившихся в созданной ей сельскохозяйственной школе, с передовыми идеями великих педагогов К.Д. Ушинского и В.П. Вахтерова в конце XIX - начала XX веков, а также их значимость в развитии отечественной теории воспитания.

Ключевые слова: сельскохозяйственная школа, нравственное воспитание, средства нравственного воспитания, личность учителя, убеждение, нравственное внушение.

Озабоченная созданием народной школы нового типа княгиня не могла обойти вниманием публикации по такому вопросу, как нравственное воспитание в начальной школе. Более того: в ее педагогических взглядах и опыте обнаруживаются заметные следы идей этих авторов в отчетах Талашкинской сельскохозяйственной школы Тенишевой и в ее книге «Впечатления моей жизни» [4].

Одной из важнейших идей, выдвинутых учеными, была идея о роли личности учителя в нравственном воспитании. К.Д. Ушинский писал: «Воспитатель..., поставленный лицом к лицу с воспитанниками, в самом себе заключает всю возможность успехов воспитания...Влияние личности воспитателя на молодую душу составляет ту воспитательную силу, которую нельзя заменить ни учебниками, ни моральными сентенциями, ни системой наказаний и поощрений» [6, с. 140]. Ученый описывает образ сельского учителя, обладающий такой «воспитательной силой»: «...Чтобы жизнь его не только не подавала повода к соблазну, не только не разрушала уважения к нему в родителях и детях, но, напротив, служила примером как для них, так и для других, и не противоречила его школьным наставлениям. Только при этом условии он может иметь нравственное влияние на детей, и его школьная деятельность будет истинно-воспитательной деятельностью» [7, с. 19].

По мнению В.П. Вахтерова, нравственное влияние 
личности учителя-воспитателя на личность ученика обусловлено авторитетом учителя, в основе которого лежит любовь и уважение к учителю, а затем уже привычка подчиняться к нему. Любовь ребенка - эхо любви учителя к нему. «Уважение детей учитель приобретает безукоризненностью своего поведения и всего образа жизни, своим умственным и нравственным превосходством» $[1$, c. 59]. В дополнение к названным благородным качествам личности, обеспечивающим авторитет учителя со стороны учеников, В.П. Вахтеров выделяет трудолюбие, дисциплинированность, доброту, такт, умение владеть собой и так далее. Такой «...учитель сам из себя представляет наглядное пособие» нравственности [1, с.71].

Под влиянием идей К.Д. Ушинского и В.П. Вахтерова княгиня М.К. Тенишева сформулировала свои требования к личности сельского учителя, как к идеалу народного учителя. «...Деревенский учитель должен быть не только преподавателем в узком смысле слова, то есть от такого-то до такого-то часа давать уроки в классе; но он должен быть и руководителем, воспитателем, должен сам быть сельским деятелем, всеми интересами своими принадлежать к деревенской среде; знать сельское хозяйство, хотя бы в какой-нибудь маленькой отрасли его, быть если не специалистом, то любителем, например, огородничество, садоводство или пчеловодство, чтобы подавать пример своим ученикам, приучать их к труду; пробудить сознательное отношение и любовь к природе; а кроме того, он должен быть их первым учителем нравственных правил, чистоплотности, порядочности, уважения к чужой собственности....Ему надо заронить в душу своих питомцев искру Божию» [4, с. 140].

К.Д. Ушинский и В.П. Вахтеров в своих научных статьях предложили методику нравственного воспитания, основанную на идеях гуманизма. К.Д. Ушинский писал: «Дорога человеческого воспитания есть убеждение, а на убеждение можно только действовать убеждением... Если личность воспитателя значит все в деле воспитания, то каким же образом действовать на личность иначе, как не путем убеждения, - путем педагогического воспитания» [5, с. 31,32].

Можно предположить, что в контексте изложенной выше идеи автор видел сущность понятия «убеждение» как процесс передачи ученикам моральных представлений посредством разъяснений.

В.П. Вахтеров считал, что при влиянии учителя на учеников «нужна и искренность, и сила убеждения» $[1$, c. 7]. Он теоретически модернизировал метод убеждения, усилив его влияние на сознание способом влияния на подсознание - внушением, которое используется в гипнозе. Ученый подчеркивал, что способ гипноза ненормален, вреден для здоровья гипнотизируемого, а способ внушения, основанный на убеждении и приме- ре, признается нормальным, здоровым и естественным. Этот метод получил у автора название - «нравственное внушение».

В.П. Вахтеров в своей статье излагает рекомендации учителю о том, как добиться того, чтобы нравственное внушение имело действие на ребенка [1, с. 61-62]. Чтобы не отвести внимание от нашей проблемы, воспроизведение этих рекомендаций в статье мы не сочли необходимым.

В.П. Вахтеров рассматривает организацию межличностных отношений и их положительное влияние на детей как способ нравственного воспитания. «...Предмет этики, - писал В.П. Вахтеров, - отношение людей друг к другу, а, стало быть, научить этим отношениям ребенка возможно только тогда, когда он будет находиться в обществе других людей...Нет никакой возможности сделать ребенка нравственным, удалив его от других детей. Совершенно так же стоит вопрос об отношении обоих полов друг к другу...Совместное обучение мальчиков и девочек усиливает благородное влияние сообщества учащихся на каждого из них...Девочки отвыкают от жеманства, становятся более самостоятельными и независимыми, а мальчики - от грубости, делаются более мягкими, вежливыми во взаимных отношениях» [1, с. 119].

В гармонии отношений мальчиков и девочек друг к другу, возникших в школе на началах симпатии, справедливости, равенства, по мнению ученого, станет мощным фактором поведения на всю последующую жизнь.

Данная идея получила свое применение в организации нравственного воспитания в школе княгини М.К. Тенишевой. В требования к учащимся входило: «безусловная вежливость в обращении как с преподавателями, товарищами, так и с посторонними лицами, исполнительность, послушание и доброе отношение к товарищам» [2, с. 52]. «Для отдыха, сна и занятий по рукоделию девочки имели при школе совершенно отдельное здание, а все остальное время, проходя одинаковые курсы наук в классах, исполняя одинаковые работы и дежурства по хозяйству школы и участия в общих играх, находятся вместе с мальчиками. Трехлетний опыт совместного времяпровождения дает право думать, что постоянное общение учеников и учениц благотворно действует на нравы мальчиков, так как в присутствии воспитанниц ученики не только не решаются сделать что-нибудь неприличное, но даже воздерживаются от бранных слов, и, начиная с малых лет вместе свое образование и постоянно видя друг в друге товарища, привыкают к обоюдному уважению. Кроме того замечено, что ученицы всегда с большей аккуратностью относятся к порученным им работам, что, в свою очередь, заражают и мальчиков» $[2$, с. 13]. 
Благоприятные условия и порядок в школе К.Д. Ушинский и В.П. Вахтеров также считали средствами нравственного воспитания. Они приучают детей к организованности, соблюдению необходимых требований и к поддержанию порядка.

Талашкинскую школу отличал безукоризненный порядок организации жизни и учебной деятельности детей. «Классные занятия продолжались с 1 января по 1 апреля и с 15 сентября по 19 декабря, всего 130 дней. Зимние классные занятие учеников начинались ежедневно в 8 часов утра и, после 4-го урока, в 11 часов 50 минут кончались. Каждый урок длился 50 минут...Те преподаватели...стремились к тому, чтобы ученики возможно лучше усваивали задаваемые вновь уроки еще в классе во время их объяснений. С 8 - 10 часов время для учеников свободное, которое они употребляют по своему усмотрению или на подготовление уроков, или на игру на балалайках и хоровому пению, или просто отдыхают. Любимым развлечением учеников во время отдыха были: зимой - бега на лыжах и коньках, а летом - игра в мяч. Во всех развлечениях и играх учеников всегда участвовали почти все преподаватели» [3, с.15].
В.П. Вахтеров считал, что правильно поставленная дисциплина «...может содействовать целям нравственного воспитания». По его мнению, поощрение и наказание способствуют поддержанию порядка и дисциплины в школе, но предупреждал о необходимости разумного их использования. В школе М.К. Тенишевой телесные наказания учеников как мера поддержания дисциплины были запрещены. Для этого применялись меры поощрения и наказания, о чем сказано в годовых отчетах: «Мерами предупреждения проступков (главным образом лености и грубости) служат убеждения, выговоры, лишения отпуска, запись в штрафном журнале и, наконец, исключение. Наиболее преуспевающие в науках или в практических работах и отличившиеся примерным поведением ученики...награждались или устною похвалою, или похвальным листом, или же похвальным листом с книгою» [2, с. 53].

Описанные в статье факты соотнесения опыта М.К. Тенишевой с передовыми идеями К.Д. Ушинского и В.П. Вахтерова о нравственном воспитании показывают принятие и творческое применение их княгиней, что способствовало созданию сельскохозяйственной школы «нового типа».

\section{ЛИТЕРАТУРА}

1. Вахтеров В.П. Нравственное воспитание и начальная школа. М.: Педагогика, 1987. - С. 43-139.

2. Годовой отчет за 1903 год о состоянии Талашкинской низшей сельскохозяйственной школы 1-го разряда, учрежденной княгиней М.К. Тенишевой. Смоленск, 1904. - 63 с.

3. Годовой отчет за 1904 год о состоянии Талашкинской низшей сельскохозяйственной школы 1-го разряда, учрежденной княгиней М.К. Тенишевой. Смоленск, 1905. -63 с.

4. Тенишева М.К. Впечатления моей жизни. М.: Искуство, 1991. - 287 с.

5. Ушинский К.Д. 0 нравственном элементе в русском воспитании. Собр. Соч. Т.2. М.: АПН РСФСР, 1948. - С. 425-488.

6. Ушинский К.Д. 0 пользе педагогической литературы. Собр. Соч. Т.2. М.: АПН РСФСР, 1948. - С. 15-41.

7. Ушинский К.Д. Проект учительской семинарии. Собр. Соч. Т.2. М.: АПН РСФСР, 1948. - С. 513-553.

8. Эрдман 0.Э. Реализация педагогических идей М.К. Тенишевой в условиях развития вариативного образования на селе: ....дис. канд. пед. наук: 13.00.01/ Эрдман Ольга Эдуардовна. - М., 1999. - С. 24-26.

( ж) Жанков Алексей Алексеевич (al_zh_xx@mail.ru).

Журнал «Современная наука: актуальные проблемы теории и практики» 